\title{
Rok 2016
}

Rok poprzedni obfitował w historii w ważne wydarzenia, które wpłynęły na dalszy rozwój dziejów politycznych i historycznych. Najważniejsze z nich to tysięczna rocznica zgonu księcia kijowskiego Włodzimierza Wielkiego, wyniesionego na ołtarze i cenionego przez historyków nie tylko rosyjskich i ukraińskich. Na zachodzie ważnym wydarzeniem było podpisanie 800 lat temu Wielkiej Karty Swobód przez króla angielskiego Jana bez Ziemi, z którym spotykamy się często w filmach i serialach o przygodach Robin Hooda. Dawne wieki przyniosły także dla Polski ważne wydarzenia, czym stało się przed 600 laty urodzenie Jana Długosza, znakomitego historyka, a także polityka i ekonomisty dbającego o rozwój Uniwersytetu Krakowskiego a także organizującego budowę słynnych domów Długosza w Sandomierzu, Wiślicy czy Korczynie.

Przed 300 laty zmarł słynny król francuski Ludwik XIV, twórca potęgi Francji, ale także systemu władzy absolutnej. W Polsce 50 lat później król Stanisław August Poniatowski powołał Szkołę Rycerską, której gmach stanowi dzisiaj budynek rektoratu Uniwersytetu Warszawskiego.

Dwieście lat temu zgasła gwiazda Napoleona, doznał on klęski w bitwie pod Waterloo i ostatecznie abdykował, został dożywotnim więźniem na Wyspie św. Heleny. Kongres wiedeński zakończył obrady, powołano Królestwo Polskie pod berłem cara Rosji Aleksandra I, a rok później powstał Uniwersytet Warszawski.

W 1815 roku urodził się Otton von Bismarck, po latach twórca potęgi Cesarstwa Niemieckiego i jego kanclerz. Na terenie dawnych ziem polskich germanizował Polaków i wprowadzał różne formy prześladowania polskości w kulturze, języku, a nawet w historii. Co ciekawe, Bismarck znał język polski i zręcznie posługiwał się polszczyzną. 
Przed stu laty w 1915 roku urodziło się wielu utalentowanych twórców i artystów, którzy w ubiegłym roku obchodzili lub mogli obchodzić stulecie swoich urodzin: Danuta Szaflarska, Edith Piaf, Frank Sinatra, Jeremi Przybora, ks. Jan Twardowski, Tadeusz Kantor, Anthony Quinn, Billie Holiday. Wydarzeniem niewątpliwe trwałym i fascynującym nawet wybitne umysły stało się ogłoszenie w 1915 roku przez Alberta Einsteina ogólnej teorii względności.

Ale czas przejść do wydarzeń z lat, które zawierają liczny 16 i 66 i które także są liczne i znaczne dla rozwoju historii, nauki i kultury, a zwłaszcza literatury.

Rok 2016 jest rokiem Arystotelesa, który urodził się w 384 roku p.n.e. i żył 62 lata. Uznany został za najwybitniejszego i najwszechstronniejszego myśliciela Starożytności. Od jego urodzin minęło w tym roku 2400 lat. Mało było w dziejach osób, które mogłyby dorównać Arystotelesowi w wiedzy i badaniach oraz analizach. Urodzony w Stagirze w Tracji nazywany jest też Stragirytą. Jego ojciec Nikomach był lekarzem nadwornym Filipa II, króla Macedonii. Arystoteles wyrastał więc w środowisku władzy i arystokracji, ale już w 17 roku życia udał się do Aten, gdzie został uczniem, a później współuczestnikiem prac i dysput naukowych Platona. W Akademii przebywał 20 lat i studiował liczne nauki, a zwłaszcza retorykę, filozofię, matematykę, astronomię, politykę pod kierunkiem Izokratesa i Platona. Po zgonie Platona nie został jednak wybrany na jego następcę. Opuścił Ateny i przebywał w Assos w Azji, gdzie założył własną akademię, w której prowadził aktywność nauczycielską przez siedem lat. Z kolei wykładał na Lesbos, by w 343 roku podjąć obowiązki wychowawcy syna króla Filipa - przyszłego władcy Aleksandra Macedońskiego. Jako znany uczony i syn byłego lekarza królewskiego został zaproszony do tej zaszczytnej i ważnej pracy nauczycielskiej. Miał już 40 lat i ponad 20 lat aktywności naukowej. Przypominam to, dlatego, że pojawiają się opinie, że jako młody człowiek został opiekunem naukowym królewicza. Aleksander urodził się w 356 roku, czyli miał lat 13, gdy został uczniem ponadczterdziestoletniego Arystotelesa. Opieka nad Aleksandrem trwała prawie siedem lat i było to ważne dla rozwoju przyszłego władcy. W 353 roku Arystoteles powrócił do Aten, gdzie założył własną szkołę nazwaną Likejon, bo działała w miejscu poświęconym Apollinowi Lykejskiemu. Stąd wywodzi się nazwa liceum, która podobnie jak akademia, została upowszechnione jako określenie typu szkoły prowadzącej do dojrzałości, czyli matury. W Lykejonie Arystoteles działał do 323 roku, czyli zgonu Aleksandra i ożywienia postaw antymacedońskich w Grecji. Wyjechał do Chalkis na Eubei, gdzie wkrótce zmarł w 322 roku. Przeżył 62 lata, z tego 
ponad 40 poświęcił nauce i nauczaniu. Zostawił po sobie nie tylko liczne dzieła, ale zapoczątkował też różne rozwijane do dzisiaj nauki. Swoje poglądy najczęściej zapisywał i przedstawiał w szkicach wykładowych i skryptach.

Prace Arystotelesa z logiki to Organom, z przyrody - Fizyka w ośmiu księgach, te, które rozwinęły się poza fizyką określił jako Metafizyka i obejmuje ona jego poglądy filozoficzne. Inne opracowania to Etyka eudemejska, Etyka nikomachejska, Etyka wielka; nauki społeczne zawiera Polityka, teorię sztuki Poetyka i Retoryka. Arystoteles położył podwaliny pod wszystkie niemal nauki, dla których jego poglądy stanowią trwałe podstawy. Zwłaszcza widoczne jest to w logice, psychologii, filozofii, etyce. Nadal aktualna jest jego definicja prawdy, w której sąd o sprawie musi być zgodny z rzeczywistością. W pedagogice wyróżniał trzy strony wychowania: fizyczną, moralną i umysłową.

Jest także prekursorem teorii harmonijnego rozwoju człowieka. Zwracał uwagę na potrzebę stałego rozwijania metod kształcenia i wychowania oraz treści i celów. To tylko najbardziej istotne i powszechnie znane zasługi Arystotelesa dla działalności naukowej i nauczania. Stały się podstawą ideałów kształcenia w systemie szkolnym i uniwersyteckim. Także polski system kształcenia nie tylko oparty jest na naukach i wskazaniach Arystotelesa, ale także uczelnie i wybitni uczeni polscy rozwijali i kontynuowali nauki i badania Arystotelesa. Ważnym ośrodkiem upowszechniania i rozwoju nauk Arystotelesa był i jest Uniwersytet Krakowski, a obecnie Jagielloński. Innym ważnym ośrodkiem był Uniwersytet Wileński. Myśli Arystotelesa rozwijali i popularyzowali tak znani twórcy i uczeni jak: Andrzej Frycz-Modrzewski, Piotr Skarga, Stanisław Orzechowski, Stanisław Petrycy, a z uczonych współczesnych Kazimierz Twardowski, Tadeusz Kotarbiński, Kazimierz Ajdukowicz, Tadeusz Czeżowski, Michał Krąpiec, Mieczysław Gogacz, Jerzy Rebeta i liczni inni szukający podstaw w nauce jako prawdzie o rzeczywistości.

Arystoteles stworzył i rozwinął wiele cennych poglądów w różnych naukach. Warto do nich sięgać i trzeba przypomnieć, że ich początki powstawały prawie 2400 lat temu w umyśle i wyobraźni genialnego Stagiryty, twórcy Likejonu i nauczyciela Aleksandra Macedońskiego.

Arystoteles wprowadza nas w daleką przeszłość i pokazuje, jak dawne są tradycje naszej nauki i skutecznej edukacji. Ale także historia polityczna i dzieje wojen oraz podbojów są bardzo odległe, a uczeń Arystotelesa Aleksander 2350 lat temu wyruszył z wojskiem na wyprawę przeciwko Persom. Przekroczył Hellespont, wygrał pierwszą bitwę nad rzeką Granik, zdobył Gordium i rozciął słynny węzeł gordyjski. Dalsze losy młodego władcy są znane. Rozbił Persję, zapoczątkował epokę hellenistyczną. Stał się jedną 
z najważniejszych postaci w historii i najwybitniejszym wodzem, na którym wzorowali się tak wybitni jak Cezar i Napoleon. W tej samej epoce też 2350 lat temu w Chinach sporządzono pierwszy katalog gwiazd stałych i skatalogowano 800 takich gwiazd; a 200 lat później opisano wybuch gwiazdy supernowej w konstelacji Scorpiona. Takie obserwacje były możliwe w astronomii 2150 lat temu. A jednocześnie Chińczycy rozpoczęli 2230 lat temu budowę muru na granicy swego państwa przed najazdami ludów stepowych. Ten potężny mur dzisiaj widoczny jest dla kosmonautów, których wysyłamy w przestrzeń okołoziemską i na księżyc.

W tej dawnej epoce tworzono także wielkie budowle i piękne dzieła sztuki. Już 2240 lat temu w 224 roku p.n.e. Filon z Bizancjum opisał siedem cudów współczesnego sobie świata. Były wśród nich piramidy egipskie, mury Babilonu, latarnia w Aleksandrii, świątynia Artemidy w Efezie, posąg Zeusa w Olimpii, Mauzoleum w Halikarnasie i posąg Heliosa na Rodos. Zeus Fidiasza wyrzeźbiony 2450 lat temu liczył 12 metrów wysokości i był wykonany w chryzelefantynie z jednej tony złota i tony kości słoniowej. Sto lat później Pyteos zbudował grobowiec Mauzolosa w Halikarnasie, który otaczało 200 rzeźb, a na szczycie umiejscowiono rzeźbioną kwadrygę. Takie to były czasy, w których żył i pracował Arystoteles. Ta wspaniała epoka wodzów, uczonych i artystów miała jednak swój koniec. Już w 86 roku p.n.e., czyli 2102 lata temu, wódź rzymski i dyktator Sulla zdobył Ateny i po 60 latach Grecja stała się rzymską prowincją - Achają. Ale i świetność Rzymu minęła, w 476 roku, czyli 1540 lat temu, ostatni cesarz został złożony z tronu po zajęciu Italii przez Germanów. Był to Romulus Augustus noszący takie samo imię jak założyciel Rzymu. Dzisiaj możemy te wydarzenia przypominać sobie, oglądając sztukę Durrenmatta, w której ostatni cesarz Rzymu ukazany, jako zdziecinniały starzec jest bohaterem tytułowym.

Lata z liczbami 16 i 66 miały także w historii Polski swoje ważne wydarzenia. Aktualnie obchodzimy 1050 rok przyjęcia chrześcijaństwa przez naszego historycznego władcę Mieszka I, który organizował pierwszy historyczny system państwowy. Nawiązywał sojusze, wchodził w układy z cesarstwem, poszerzał swoje ziemie i wymagał nie tylko wyższego poziomu cywilizacji i kultury, ale także uznania na arenie europejskiej i w środowisku chrześcijańskim. W roku 965 pojął za żonę księżniczkę czeską Dobrawę, a w rok później zorganizował chrzest swoich poddanych. Polska weszła do wspólnoty chrześcijańskiej. Zmieniała się religia i zmieniała kultura. Ożywiły się związki z zagranicą. Przybywali do Polski kapłani i podejmowali zadania chrześcijańskie oraz urzędnicze w kancelarii książęcej, administracji kościelnej, szkołach i klasztorach. Mieszko miał z Dobrawą dwoje dzieci: Bo- 
lesława i Świętosławę. Bolesław został następcą ojca, a Świętosława w kolejnych ożenkach królową Szwecji, Danii i Norwegii, zapewniając tym samym ojcu, a później bratu dobre relacje z państwami nordyckimi. Mieszko ożenił się powtórnie z Odą i miał z nią trzech synów, którzy zgłaszali pretensje do tronu polskiego. Bolesław Chrobry jednak ich odsunął, a na swojego następcę wyznaczył młodszego syna Mieszka. Tu trzeba zatrzymać się przy imionach dziada i wnuka.

Właściwie to nie wiemy, jakie imię miał nasz pierwszy historyczny władca. Dokument, jaki wystawił dla papieża nosi nazwę Dagome Judex, co skłania niektórych historyków, że może nosił imię Dogobert lub Dogo, jako nadane przy chrzcie. Mieszko nie było bowiem imieniem tylko przydomkiem oznaczającym „Ślepotkę”. Sam Gall w swojej kronice wspominał, że Mieszko w dzieciństwie oślepł i dopiero po jakimś czasie odzyskał wzrok, co interpretowano jako nawrócenie religijne pod wpływem chrztu. Językoznawcy uzasadniają formę „Mieszko” jako zastępczą nazwę, którą później przejęto w dynastii i rozszerzono na Mieczysław. Mieszko miał dwu braci, jeden to Czcibor, a imienia drugiego nie znamy. Bolesław Chrobry nadał swemu synowi przeznaczonemu na tron imię Mieszko po swym ojcu. Było to już tworzenie imiennej tradycji. Luki w historii nie pozwalają na jaśniejsze wywody, co widać u wnuka Bolesława Chrobrego, któremu nadano imię Kazimierz, a nie Bolesław. Niektórzy historycy domniemają, że Kazimierz miał starszego brata, Bolesława zwanego Zapomnianym, który panował po ojcu, ale rządził despotycznie i został usunięty lub zgładzony. Inni twierdzą, że to wymysł, a tym srogim władcą był rządzący krajem przez jakiś czas starszy syn Chrobrego Bezprym. Są to spory niejasne, ale jedno jest pewne, że Kazimierz Odnowiciel urodził się w 1016 roku, czyli tysiąc lat temu. Odbudował przy pomocy matki, krewnej cesarza, władze w państwie, odzyskał Śląsk i pozostawił swemu synowi znacznie odnowione państwo. Syn jego, Bolesław zwany Śmiałym lub Szczodrym, objął władzę, mając zaledwie 18 lat, ale po dalszych 18 latach koronował się jako trzeci król Polski w 1076 roku, co miało miejsce 940 lat temu. Za jego panowania Polska znów stała się ważnym państwem w Europie, a młody król udzielał wsparcia i interweniował na Rusi oraz na Węgrzech.

W roku 1116, czyli 900 lat temu, kończył pisać swą Kronikę Gall Anonim, zawarł tam opis rządów Krzywoustego i jego przodków, zwłaszcza Chrobrego. Też nie wiemy, skąd ten autor pochodził i jak się nazywał, a także dlaczego przerwał pisanie swego dzieła na roku 1116. Rok ten jest także datą uzależnienia Pomorza od Polski. 
Sięgnijmy do jubileuszowych wydarzeń z historii powszechnej. W 1206 roku, 810 lat temu, Czyngis Chan rozpoczął organizację swego państwa i prowadzenia podbojów. Zorganizował jedno z większych imperiów. Jego wnukowie i synowie rządzili Chinami, Syberią, podporządkowali sobie Rosję, a nawet dotarli do Polski, gdzie zadali nam klęskę pod Legnicą.

Z osłabienia Rusi i innych państw księstw rosyjskich skorzystała Litwa, która do 1366 roku podporządkowała sobie Wołyń, Podole, ziemię czernichowską i Smoleńszczyznę. Udało się to dzięki rozsądnym rządom Gedymina, który w 1316 roku został władcą Litwy, a po nim rządzili jego synowie Kiejstut i Olgierd, ojciec Jagiełły. Rządy Gedymina wpłynęły także na przyszłe losy Polski, ponieważ jego córka została żoną Kazimierza Wielkiego.

W historii Anglii rok 1066 to ważna data. Po zgonie króla Edwarda Wyznawcy tron angielski zajął Harold, mimo pierwszeństwa Wilhelma księcia Normandii. Ten postanowił odzyskać należny mu tron zbrojnie i najechał Anglię. W bitwie pod Hastings 14 października 1066 roku rozgromił wojska Harolda, głównie przez atak kawalerii i celny ostrzał łuczników. Harold zginął na polu bitwy, a zwycięski Wilhelm koronował się w Londynie 25 grudnia tego roku, zakładając nową dynastię -normandzką, której ostatnia z rodu, królewna Matylda, zostając żoną Henryka księcia Akwitanii, Gaskonii i Owernii z rodu Plantagentów, wprowadziła tę nową dynastię na tron angielski, którym władała do zdobycia go przez Tudorów - Henryk VII został królem w 1485 roku.

W 1066 roku rozpoczęła się w Anglii epoka dynastii normandzkich, która łączyła z Wielką Brytanią znaczną część Francji, co trwało do ukończenia wojny stuletniej.

Rok 1466 dla Polski to data pokoju toruńskiego po wojnie trzynastoletniej, w czasie której syn Jagiełły król Kazimierz Jagiellończyk rozbił państwo krzyżackie, zdobył Malbork, przyłączył Pomorze Gdańskie i Warmię do Polski. Utrzymał resztki państwa zakonnego jako lenno ze stolicą w Królewcu. Stało się to 550 lat temu i zasługuje na szacunek oraz uznanie militarnego wysiłku Polski i zdolności politycznych młodego króla, który znów jednoczył Polskę i Litwę pod swoim berłem.

Przejdźmy do rocznic zgonów znanych twórców i władców, który w latach z liczbami 16 lub 66 roku zakończyli życie. Pierwszym na naszej liście jest Hieronim Bosch zmarły 9 marca 1516 roku. Jego malarstwo wyrosło z późnego gotyku, ale nasycone zostało surrealizmem, co w odbiorze sugeruje, że to twórca współczesny lub co najmniej z ubiegłego wieku, zbliżony do twórczości Salvadore Daliego. Znane dzieła Boscha to Kuszenie św. Antoniego, Sąd ostateczny, Rozkosze ziemskie, Wóz z sianem, Łódź szaleńców, Siedem 
grzechów głównych, a także bardzo wymowne dzieło i tytuł Leczenie głupoty. Bosch miał licznych naśladowców, a w Antwerpii w pracowni Cooka sporządzano miedziorytnicze kopie jego dzieł.

W 1566 roku zmarł jeden z najwybitniejszych władców Turcji padyszach Sulejman Wspaniały. Rządził Turcją od 1520 roku przez 46 lat. U nas został spopularyzowany w serialu filmowym Wspaniałe stulecie, a jego trzecią żoną Hűrem była branka z terenów dawnej Polski zwana przez historyków Roksolaną. Warto przy okazji zwrócić uwagę, że w ostatnim roku w programach telewizyjnych więcej było tematyki o życiu i obyczajach Turków niż innych narodowości.

W roku 1616 zmarło dwu wybitnych pisarzy, którzy nadal są znani, cenieni i popularni. Pierwszy z nich to Miguel Cervantes autor Don Kichota, słynnej powieści w trzech częściach, w której fantastyczna fabuła łączy się $\mathrm{z}$ satyrą i humorem, a także występują $\mathrm{w}$ treści elementy symboliczne przepojone wieloznacznością. Ale dzieło to budziło od początku zainteresowanie i liczni naśladowcy próbowali je naśladować i rozwijać. Dobrze, że autor zakończył i wydał ostatnią część w 1615 roku. Już ponad 400 lat cieszymy się jego treścią, na której podstawie powstały inscenizacje, opery i widowiska, a w ostatnim okresie także filmy. Twórczość Cervantesa jest dość bogata. Pisał dramaty, zwłaszcza komedie, poematy heroikomiczne, romanse, okolicznościowe poezje. Wydane w pierwszej połowie XX wieku jego dzieła obejmują 11 tomów, ale powszechnie znany jest głównie Don Kichot uznawany za pierwszą powieść europejską, a jednocześnie będący krytyką średniowiecznych romansów rycerskich na rzecz renesansowego sceptycyzmu poznawczego. W Polsce tłumaczenie Don Kichota ukazało się w 1786 roku, wcześniej upowszechniane było w języku francuskim, stąd brzmienie imienia „Kiszot”, chociaż w oryginale hiszpańskim zapis Don Quijote, co wymawiane jest, jako „don Kihote”, a nie podoba się niektórym naszym pseudoperfekcjonistom.

Drugi wielki autor, a na pewno największy w dziejach dramaturg, to William Szekspir, młodszy od Cervantesa o 17 lat, także zmarł w 1616 roku 22 kwietnia. Był aktorem, pracownikiem teatru, udziałowcem i autorem. Pierwsze jego utwory to poematy: Venus i Adonis, Lukrecjo z 1594 roku, które napisał, gdy miał 30 lat. Później tworzył dramaty: tragedie i komedie. Łącznie napisał 38 dramatów. Do najbardziej znanych należą Romeo i Julia, Makbet, Hamlet, Othello, Król Lear, Ryszard III, Cezar i Kleopatra. W grupie komedii szczególnie ulubione to Poskromienie złośnicy, Sen nocy letniej, Burza, Wieczór trzech króli, Wiele hałasu o nic. Twórczość Szekspira budziła stale zainteresowanie. Czytano i oglądano inscenizacje teatralne. W sumie napisał 
ponad 40 utworów, z których część wydano po jego zgonie. Ale co najmniej 20 jest wciąż wystawianych na scenach teatrów, filmowanych lub inscenizowanych w programach telewizyjnych. Najbardziej znany i ceniony jest Hamlet, wielokrotnie filmowany przez tak znanych reżyserów jak Olivier, Zeffirelli czy u nas Wajda w inscenizacji telewizyjnej. Z rolą Hamleta i inscenizacją tego utworu związany był zwłaszcza Adam Hanuszkiewicz, który już w 1951 roku zagrał rolę królewicza duńskiego na scenie Teatru Polskiego w Poznaniu, a później dwukrotnie reżyserował ten dramat w Warszawie.

Jedną z najstarszych inscenizacji dramatu Szekspira było wystawienie Romea i Julii w 1789 roku w Teatrze Narodowym w Warszawie. Chętnie i często Szekspira tłumaczono, a do najwybitniejszych tłumaczy należeli Jan Kasprowicz, Konstanty I. Gałczyński, Jarosław Iwaszkiewicz. Maciej Słomczyński przetłumaczył wszystkie dramaty Szekspira wydane w 39 tomach w latach 1979-1988, a Stanisław Barańczak przetłumaczył 25 dramatów i Sonety znakomitego twórcy.

Dzieła Szekspira i sama osoba autora budziły od dawna różne podejrzenia: czy to on był autorem i sam pisał, czy też udzielał komuś swego nazwiska, kto wolał zostać anonimowy. Analizy tekstów raczej wskazują na jednego autora, ale czy był nim Szekspir, który pracę w teatrze londyńskim zaczynał od pilnowania koni w stajni? Te zagadki pobudzają dociekliwych szekspirologów, co nie osłabia wartości tej genialnej twórczości, która dla tak wielu utworów nie stanowi autonaśladownictwa, bo każdy jest inny w treści, czasie akcji, rodzaju bohaterów, a nawet miejsc geograficznych akcji, dziejącej się w Anglii, Szkocji, Danii, Grecji, Rzymie, Wenecji i na Cyprze. W końcowej części Hamleta występuje nawet polski motyw.

Warto czytać i poznawać inscenizacje Szekspira, jego dzieła powstałe przed laty są nadal żywe, ciekawe, z głęboką myślą i refleksją; pozwalają na bogate aranżacje sceniczne czy filmowe lub telewizyjne.

W roku 1816 ukazało się najpełniejsze wydanie Śpiewów historycznych Juliusza Niemcewicza, znanego głównie jako autora komedii politycznej Powrotu posła. W komedii bronił reform sejmu czteroletniego i ośmieszał ich przeciwników, których i w sejmie, i poza sejmem było sporo, z żenującymi „argumentami”. Niemcewicz walczył nie tylko pismem, ale także zbrojnie, jako adiunkt Tadeusza Kościuszki. Już wcześniej zaczął pisać dłuższe utwory historyczne określane jako Dumy polskie. Pierwsze ich wydanie ukazało się już w 1789 roku. Ukazywały się w ciągu 25 lat kolejne ich części, opiewające życie i działania królów i władców Polski, wodzów i słynnych rycerzy jak Zawisza Czarny. W roku 1816 wydano najszerszy ich zbiór, bo 32 pieśni od Piasta do Jana III Sobieskiego. Poprzedzone były tekstem Bogurodzicy, 
a zamknięte „pieniem żałobnym” pt.„Pogrzeb księcia Józefa Poniatowskiego. Zyskały ogromną popularność i wkrótce ukazały się kolejne wznowienia, nawiązania i kontynuacje przez poetów romantycznych (Lenartowicz, Siemieński) były tłumaczone na język francuski i niemiecki. Znani kompozytorzy, jak Karol Karpiński czy Maria Szymanowska, tworzyli dla tekstów pieśni ujęcie muzyczne. W kolejnych wydaniach wzbogacano je ilustracjami w wykonaniu między innymi Juliusza Kossaka i Henryka Pillatiego.

Śpiewy historyczne stały się ważnym dziełem sławiącym postacie historyczne i wydarzenia oraz czyny bohaterów. Przeważało w nich regionalne przedstawienie tematów historii $w$ wierszowanym opracowaniu o postaciach i wydarzeniach. Zaciekle zwalczane były przez rządy zaborcze, zwłaszcza przez Nikołaja Nowosilcowa. Stanowią ważny pomnik w dziejach literatury narodowej i zasługują na przypomnienie w 200 rocznicę pełnego wydania.

Sto lat temu, 21 listopada 1916 roku, zmarł jeden z najdłużej panujących monarchów świata cesarz Franciszek Józef I z dynastii habsbursko-lotaryńskiej. Urodzony 18 sierpnia 1830 roku, na tron wstąpił w grudniu 1948 roku, panował 68 lat jako cesarz Austrii, a od 1867 roku także węgierski król w systemie Austro-Węgier. Jego panowanie nie przyniosło cesarstwu żadnych większych wartości ani w polityce, gospodarce czy kulturze. Idee demokratyczne z okresu Wiosny Ludów zdołał zneutralizować, zniósł konstytucją sejmy krajowe i następstwa polityczne z czasu rewolucji 1848 roku. $\mathrm{Na}$ arenie międzynarodowej poniósł porażki w wojnach $\mathrm{z}$ Włochami wspieranymi przez Francję i z Prusami. Austria utraciła tereny we Włoszech, a Prusy rozwinęły się po wojnie 1870 roku w Cesarstwo Niemieckie, z którym zawarł w 1882 roku trójprzymierze, co stało się przygotowaniem do konfliktu I wojny światowej. Austria zagarnęła tereny Słowian południowych: Bośnię i Hercegowinę, wchodziła w konflikt z Serbią i wspierającą ją Rosją, co spowodowało zabójstwo następcy tronu Ferdynanda w Sarajewie w czerwcu 1924 roku i wybuch I wojny światowej, z której monarchia austriacka wyszła zupełnie zdruzgotana. Utraciła ziemie Czech i Słowacji, Węgier, Siedmiogrodu i Polski, a także południowych Słowian, którzy utworzyli Królestwo Serbii-Chorwacji-Słowenii, a później Jugosławii. Austria z wielkiej monarchii stała się małym państwem, do którego zakazano wstępu rodzinie ostatniego cesarza Karola. Długie panowanie Franciszka Józefa wypełniły także klęski osobiste: śmierć jedynego syna, żony - słynnej cesarzowej Sisi, a także brata cesarza Maksyma. Dzisiaj dzieje rodziny cesarskiej są tematyką filmów i problemem do rozważań nad zmiennością losów nawet wielkich państw i długowiecznych monarchów. 
Sto lat temu, 15 listopada w Vevey w Szwajcarii, zmarł Henryk Sienkiewicz, jeden z najwybitniejszych pisarzy polskich, laureat literackiej $\mathrm{Na}-$ grody Nobla. Od jego zgonu minęło 100 lat, a od urodzenia 5 maja 1846 roku - 170. Jest więc rok 2016 uznany Rokiem Sienkiewicza w podwójnym znaczeniu jubileuszu: urodzin i zgonu. Już za życia zdobył ogromne uznanie i popularność nie tylko na ziemiach polskich, ale także w całej Europie i Ameryce. Wielu specjalistów uznaje, że Sienkiewicz jest najwybitniejszym polskim pisarzem, a jego wpływ na współczesnych był szerszy i silniejszy niż Mickiewicza, któremu złożył piękny hołd w Latarniku, a główny bohater jego Potopu, Andrzej Kmicic-Babinicz, realizuje znane wcielenie Jacka Soplicy w księdza Robaka. Sienkiewicz był bardzo aktywnym autorem, spod jego pióra wychodziły najpierw opowiadania, nowele, reportaże i listy z podróży. Bogactwo tematyki i liczba dzieł autorskich Sienkiewicza jest imponująca i tylko Józef Kraszewski przewyższa go liczbą wydanych i skatalogowanych tomów. Wspomnijmy, że Dzieła Sienkiewicza pod redakcją naukową Juliana Krzyżanowskiego wydano w 60 tomach w latach 1949-1955, a jeszcze do roku 1956 opublikowano dwa tomy listów. Sienkiewicz zaczynał twórczość od opowiadań i nowel. Ogłosił ich około 40, a są w tej dużej grupie prawdziwe perełki nowelistyki, jak Janko muzykant, Latarnik, Sachem, Bartek Zwycięzca, Na marne, Za chlebem, i inne powszechnie znane z lektur szkolnych, co może przytępia ich odbiór i osłabia wymowę artystyczną w procesie klasowej młócki. Dlatego warto czytać je spokojnie w czasie wolnym.

W pierwszym okresie twórczości wydał Sienkiewicz jeszcze tak zwane małe powieści czy też dłuższe opowiadania: Szkice węglem, Hania, Stary sługa, Na marne.

W 1830 roku zajął się Sienkiewicz tematyką historyczną, wydał ciekawą nowelę Niewola tatarska i wszedł w krąg zagadnień wojen polsko-tatarskich i kozackich, co doprowadziło do wydania fascynującej ówczesnych czytelników powieści historycznej Ogniem i mieczem drukowanej w odcinkach w "Słowie” w latach 1883-84, a następnie kontynuował losy swoich bohaterów w Potopie i Panu Wołodyjowskim. Dzieła te są powszechnie znane i były dawniej pilnie czytane, a wielbiciele Sienkiewicza popisywali się znajomością fragmentów tekstów. Dzisiaj możemy poznać te fabuły z inscenizacji filmowych Karola Hofmana, który ekranizację Trylogii rozpoczął od końca, przedstawiając przygody pana Michała w walkach z Tatarami i Turkami, co było znacznie słuszniejsze niż zmagania z Kozakami i Rusią, wprawdzie Kijowską, ale zawsze. Trylogia jest najchętniej czytaną i oglądaną w inscenizacji filmowej. W dawnych czasach, gdy uczyłem jeszcze w szkole, trzeba 
było zmagać się z tekstem Szkiców węglem, które też były sfilmowane, ale tak słabo, że dzisiaj nikt już tego nie pamięta.

Rok Sienkiewicza jest okazją do przypomnienia jego dzieł w lekturze i oczywiście w inscenizacjach. Prawdziwym klejnotem literackim są Krzyżacy powieść wyraźnie historyczna, dzieło doświadczonego już pisarza, z dużą dozą sensacyjnej akcji, ale służącej głównie poznaniu realiów i problemów historycznych. Budowa powieści, akcja, postaci bohaterów są znacznie ciekawiej przedstawione niż w powieści Kraszewskiego o tym samym tytule i zbliżonej treści Krzyżacy 1410. Sienkiewicz znał utwór Kraszewskiego, zapożyczył tytuł od autora Starej baśni, ale stworzył dzieło tematycznie i artystycznie znacznie dojrzalsze. Szczególną wartość w Krzyżakach ma archaizacja językowa, oparta na gwarze podhalańskiej i dawnych terenach staropolskich. Też mamy film z 1960 roku w reżyserii Aleksandra Forda, ale to już jest archeologia kinematografii z wieloma umownościami. Obiecywano nam przygotowanie nawet dwu inscenizacji filmowych Krzyżaków na 600-lecie wiktorii grunwaldzkiej, ale jakoś nie wyszło. Sienkiewicz nie jest łatwy do filmowania, czego przykładem są inscenizacje Rodziny Połanieckich i Quo vadis. Są one ważne dla popularyzacji twórczości Sienkiewicza i zachęcania do lektury, ale arcydzieła sztuki filmowej to nie są. Ukazują jednak, że autor Krzyżaków podejmował tematykę społeczną swoich czasów i odważył się sięgnąć do starożytności z epoki Nerona oraz Świętego Piotra. Quo vadis zresztą jest powodem pewnego zamieszania przy biografii Sienkiewicza, powszechnie panuje przekonanie, że za ten utwór otrzymał nagrodę literacką Nobla. Nie jest to zgodne z prawdą, bo na dyplomie eksponowanym w Oblęgorku nie ma takiego zapisu, ponieważ nagrodę Nobla z literatury otrzymuje się za całokształt twórczości. Sam Sienkiewicz, odbierając dyplom, w przemówieniu laureata mówił o znaczeniu literatury dla pokrzepienia serc. Nawiązał do zakończenia Trylogii, co po latach przypomniał kolejny laureat Wiliam Faulkner.

Sienkiewicz laureatem został w 1905 roku, natomiast Quo vadis zostało wydane w 1896, a Krzyżacy w 1900, Na polu chwały ogłoszone w 1903-1904, czyli też przed nagrodą, na którą ta część twórczości złożyła się w istotny sposób. Ale bezkrytyczna dowolność akcentowania wartości utworu w treści z początków chrześcijaństwa wynosiła Quo vadis, jako decydujący o nagrodzie, mimo że powieść powstała 10 lat wcześniej.

Podobnie jest z Reymontem, uważa się, że jego nagroda została przyznana za Chłopów, chociaż utwór ten ogłoszony został w częściach do roku 1908, a nagrodę otrzymał Reymont w 1924, czyli 16 lat później. Ale przed uzyskaniem nagrody ogłosił kilka opowiadań, powieść Wampir, dramat Prze- 
grana i trylogię historyczną Rok 1794 w trzech częściach: „statni sejm Rzeczypospolitej, Insurekcja, Non desperantum. To także poważny dorobek. Łączenie nagrody tylko $\mathrm{z}$ utworem sprzed 16 lat jest prymitywnym uproszczeniem.

Warto także zwrócić uwagę, że nagrodę Nobla uzyskaną przez Sienkiewicza przypisywano Rosji, bo autor Krzyżaków był poddanym cara rosyjskiego.

O Sienkiewiczu i jego utworach pisano dużo i często. Prawdziwym wielkim znawcą w tej dziedzinie był Julian Krzyżanowski, autor m.in. Kalendarza życia i twórczości Henryka Sienkiewicza oraz popularnego opracowania Żywot i sprawy Henryka Sienkiewicza. Już za życia pisali o nim Stanisław Tarnowski, Piotr Chmielowski, w współcześnie Andrzej Stawar, T. Bujnicki, Z. Szweykowski, A. Nofer-Ładyka. W ostatnim okresie Barbara Wachowicz ogłosiła kilka studiów i reportaży o życiu i twórczości Henryka Sienkiewicza, z interesującym cyklem tekstów ogłoszonych dla uczczenia Roku Sienkiewicza.

Szczególnie cenną właściwością Sienkiewicza była troska o innych, pomoc w trudnych sytuacjach, inicjowanie działań i ruchów społecznych oraz narodowych. Warto przypomnieć List otwarty do Jego Cesarskiej Majestatu Wilhelma II króla polskiego w obronie dzieci polskich we Wrześni prześladowanych przez pruskie władze oświatowe, ufundowanie stypendium dla pisarzy i dziennikarzy, z którego korzystała m.in. Maria Konopnicka, Stanisław Wyspiański, Kazimierz Przerwa-Tetmajer, w czasie wojny zorganizował w Szwajcarii Komitet Pomocy Ofiarom Wojny w Polsce, który dostarczał potrzebującym lekarstwa, żywność, odzież, a także pieniądze. Z Komitetem tym współpracowało wielu Polaków oraz cudzoziemców. Znaczny i cenny był udział siostry Urszuli Ledóchowskiej, organizatorki franciszkańskiego systemu szkół i form opieki nad dziećmi i młodzieżą. Późniejszej świętej, której sanktuarium znajduje się w Pniewach, a w roku ubiegłym obchodzono 150 rocznicę urodzin matki Urszuli.

Sienkiewicz był także aktywnym obrońcą godności ludzkiej, opiekunem ubogich i potrzebujących, przewodniczył towarzystwom oświatowym, wspierał tworzenie sanatorium przeciwgruźliczego dla dzieci w Zakopanem, z własnych funduszy wybudował szkołę w Oblęgorku. O prawdę, pomoc i uczciwość walczył w swych artykułach i reportażach związanych z bieżącym życiem społecznym i politycznym.

Pochowany został w Katedrze św. Jana w Warszawie. Zostały po nim jego wspaniałe dzieła, powieści, nowele i artykuły oraz pamiątki eksponowane w muzeach biograficznych Sienkiewicza w Oblęgorku, Woli Okrzejskiej i Poznaniu. Rok Sienkiewicza jest też godną formą uczczenia jego wielkości i wartości dla narodu oraz kultury i oświaty narodowej. 
W 1916 roku - 25 grudnia - zmarł w Krakowie Adam Chmielowski znany jako brat Albert, którego Jan Paweł II wyniósł na ołtarze. Adam Chmielowski urodził się w 1845 roku w Igołomi pod Krakowem, uczył się w Szkole Kadetów w Petersburgu, a także w Warszawie w Gimnazjum Realnym im. Pankiewicza, a w latach 1861-1863 w Instytucie Politechnicznym w Puławach. Przystąpił do powstania styczniowego, w bitwie pod Mełchowem stracił nogę i został poraniony. W Paryżu w 1864 roku rozpoczął studia malarskie, które kontynuował po amnestii i powrocie do kraju w Szkole Rysunku Wojciecha Gersona. Od 1866 roku studiował także na uniwersytecie w Gandawie i utrzymywał kontakty ze szkołą malarską Karola Goetza w Paryżu. Studiował także w Monachium. Od 1874 roku przebywał w Zarzeczu koło Przeworska, gdzie stworzył swoje najlepsze portrety rodziny Chojeckich oraz tak znane obrazy jak Biwak powstańców w lesie, Powstańcy, a po powrocie do Warszawy ukończył Ogród miłości, później zaś namalował Mnicha na cmentarzu, Szara godzinę, Nastrój wieczorny, Wizję św. Małgorzaty Alacoque. W późniejszym okresie stworzył Ecce Homo, Caritas, Świętą Weronikę. Tworzył także rzeźby, jak popiersie Ignacego Logoli przechowywane w klasztorze w Starej Wsi.

W roku 1880 wstąpił do nowicjatu jezuitów. W 1887 roku przyjął obłóczyny i wstąpił do franciszkanów jako bart Albert. Osiadł w Krakowie i prowadził za zgodą magistratu ogrzewalnie miejskie, a potem tworzył przytuliska dla ubogich, zakładał domy dla osieroconych dzieci, kalek, starców, tworzył pustelnie i obejmował swoją działalnością południowe ziemie Polski: Kraków, Lwów, Zakopane, Przemyśl, Stanisławów, Tarnów, Sokal, Kielce, Jarosław i inne okoliczne miejscowości, gdzie potrzebna była pomoc i opieka.

Obok malarstwa uprawiał także analizy teoretyczne i ogłosił pracę O istocie sztuki, a także liczne artykuły o tercjarstwie i jego zadaniach. Już za życia był uznany jako wyjątkowy kapłan i artysta. Pozostawał pod wpływem nauk i mistyki Jana od Krzyża, a także apostolatu św. Wincentego a Paulo. Głównymi cnotami brata Alberta była miłość Boga i miłość bliźniego. Posługę bezdomnym nędzarzom uważał za formę kultu męki Pańskiej. Zmarł w pierwszy dzień Bożego Narodzenia 1916 roku. Jego postać i czyny znajdowały upamiętnienie w licznych utworach literackich, z których do najbardziej cenionych należy trylogia Żeromskiego Walka z szatanem, a także w utworach Micińskiego, Witkiewicza, Bunscha, Nowaczyńskiego, Marcinka i wielu innych.

Osobę brata Alberta szczególnie cenił Jan Paweł II, który jeszcze, jako biskup krakowski napisał dzieło Brat naszego Boga poświęcone jego czynom, 
poglądom i wartościom. Już w 1934 roku rozpoczęto starania o beatyfikację Brata Alberta, w latach od 1946 do 1950 odbył się diecezjalny proces informacyjny, a następnie proces heroiczności cnót. Nowaczyński określił brata Alberta „Najpiękniejszym człowiekiem mojego pokolenia”, a Helena Modrzejewska ujrzała w nim ucieleśnienie wszystkich cnót chrześcijańskich i najbardziej promiennego patriotyzmu. Prezydent Mościcki nadał mu pośmiertnie wielką wstęgę Orderu Polonia Restituta. Jan Paweł II dokończył proces beatyfikacyjny, a następnie przeprowadził kanonizację i wyniósł brata Alberta na ołtarze.

Brat Albert zmarł 100 lat temu, ale jego osoba i jego wspaniałe dzieła opieki nad ludźmi są nadal nie tylko pamiętane, ale realizowane w zakładaniu domów opieki, przytułków i innych form realnej działalności dla dobra potrzebujących oraz dla upamiętnienia jego zasług i czynów.

Brat Albert jest ciągle nie tylko wzorem postępowania chrześcijańskiego, ale także inspiracją dla twórców w literaturze, malarstwie i muzyce.

W 1976 roku Chrześcijańskie Stowarzyszenie Społeczne ustanowiło nagrodę im. brata Alberta dla twórców za wybitne osiągnięcia w sztuce sakralnej.

Przypomniane fakty i osoby z historii w ujęciu tradycji sprzed 50, 100 i ich wielokrotności lat stały się od 1992 roku stałym cyklem moich opracowań autorskich początkowo na łamach „Edukacji i kultury”, której byłem redaktorem, a od 1998 roku „Rocznika Andragogicznego”. Zyskały zainteresowanie czytelników, a nawet niekiedy zdobywały uznanie. W mojej działalności autorskiej to najdłuższy cykl trwający 25 lat.

Czas jednak zamknąć ten felietonowy serial, czemu sprzyja sędziwy wiek autora oraz zmieniające się relacje międzyludzkie w środowiskach wieloletnich współpracowników, uczniów i doktorantów, a nawet dawnych przyjaciół. Zmierzam do podsumowań i swoje przemyślenia oraz analizy ogłosiłem w 2014 roku w tomie Niepokój o dydaktykę i w 2016 w Sporze o kształcenie ustawiczne. Pracuję nad bardziej osobistymi relacjami, przypominają mi się chwile i sprawy miłe oraz wartościowe, a także nieporozumienia, pomówienia i krzywdy, jakich także doznałem niekiedy od osób wydawałoby się najbliższych, których wspierałem w drodze do doktoratu, habilitacji, a nawet profesury. Niestety część moich współpracowników i przyjaciół już nie żyje, a na pewno zasługują na pamięć i dobre słowo wspomnień.

Przez wszystkie lata mojej naukowej aktywności starałem się o rozwijanie i upowszechnianie aktywności i samodzielności w uczeniu się i samokształceniu, a także w rozwoju różnych form edukacji dorosłych i kształcenia ustawicznego. Dążyłem do rozwijania i upowszechniania wartości 
w procesach edukacyjnych, modernizacji kształcenia i podnoszenia jakości. Trochę tych propozycji zgłosiłem, toteż boli mnie wiadomość o likwidacji gimnazjów, których nie rozwinięto jako aktywnych placówek kształcenia. Także rozpoczynanie nauki przez sześciolatków, poważnie zaniedbane, znów zostało odsunięte na nieokreślony czas. Już zajmujemy w Europie jedno $\mathrm{z}$ ostatnich miejsc w rozpoczynaniu wieku szkolnego. Przykładem może być dla nas Szwecja, gdzie naukę rozpoczyna siedmiolatek, ale także może sześciolatek, a nawet ośmiolatek, gdy wykazuje braki w przygotowaniu. Dlaczego z tego przykładu nie skorzystać? W Wielkiej Brytanii od pierwszej połowy XIX wieku, a więc już ponad 160 lat, naukę rozpoczynają pięcioletnie dzieci, które oczywiście są do tego przygotowywane i szkoła oferuje im bogate formy i metody opieki oraz nauki.

Sam zostałem nauczycielem 65 lat temu w 1951 roku, ale praktykę w zawodzie zamieniłem na wyższe studia nauczycielskie. Jednak od 1954 roku stale pracowałem w różnych szkołach: podstawowych, średnich, zawodowych. Wyniosłem z tej praktyki ważne doświadczenie i przekonanie o potrzebie uznawania wartości, wdrażania samodzielności i przygotowywania do samokształcenia oraz realizowania edukacji ustawicznej rozumianej jako kształcenie przez całe życie, a nie tylko jako doskonalenie zawodowe wzbogacone indoktrynacją polityczną.

Józef Pótturzycki 